\title{
Sustainable urban planning for a successful energy transition on Reunion Island : From policy intentions to practical achievement
}

\author{
Fiona Bénard-Sora ${ }^{\mathrm{a}, *}$, Jean Philippe Praene ${ }^{\mathrm{a}}$ \\ ${ }^{a}$ Laboratory of Physics and Mathematical Engineering for the study of Energy and the Environment 117 rue du General Ailleret - \\ 97430 Le Tampon - Reunion, France
}

\begin{abstract}
Numerous studies have investigated how small vulnerable territories are adapting to climate change, particularly non-interconnected islands with focus on Renewable Energy Sources (RES) and self-sufficiency. A key to success is an energy plan with appropriate policy tools. This paper first presents a discussion on barriers to RES deployment. Then, we present the energy situation and the legislative energy framework in Reunion Island. Are the legislative and policy frameworks sufficient to achieve the energy transition? This paper proposes an original view discussing the potential of a territory and available tools to develop RES. Energy transition is also view as an opportunity.
\end{abstract}

Keywords: Reunion Island, Renewable Energy, Transition, Autonomy, Policy, Energy Planning

\section{1. Introduction}

More than 730 million inhabitants live on islands, representing $11 \%$ of the world's population [1],[2]. Due to their specific characteristics including geographical situation, size, natural disasters, and energy production, small islands are highly vulnerable to climate change [3]. Isolation from markets is a real disadvantage for these territories, and this consequently causes socioeconomic vulnerability. High freight charges on imports are an example of a consequence of their situations [4 5]. The Intergovernmental Panel of Climate Change (IPCC) report, in its chapter 29, highlights the lack of specific projection studies to guide adaptation strategies [6]. Furthermore, it seems obvious that islands need alternative green energy scenarios to balance their high dependance to fossil fuel imports for electricity generation [1]. Moreover, islands are strongly marked by their incapacity to achieve economies of scale, [7]. Several islands are

\footnotetext{
${ }^{*}$ Corresponding author, Tel. +262 692295674

Email address: fiona. sora@univ-reunion.fr (Fiona Bénard-Sora)

URL: piment . univ-reunion . fr (Fiona Bénard-Sora)
} 
currently lagging behind and for many of them, their economic growth is highly dependent on their patron [7]. Local responses of human societies to face the effects of climate change are developed in very unequal conditions : small islands which are the most exposed territories to climate change are not the most emiting in terms of greenhouse gases. For these territories, this factor accentuates their vulnerability because it makes them dependent on another territory. Vulnerability and dependence are indeed two related elements. For these territories, the energy transition must be understood at first sight as the transition to electricity production from $100 \%$ renewable sources. However, a territory cannot have a purely deterministic characteristic. Indeed, it seems difficult to consider the latter as the central and decisive factor of the dynamics of the social and economic policies. The human being and its territory are intrinsically linked as land are developing by societies. Thus in a world of change, exposed to the effects of climate change, small islands have to rapidly build their resilience. Small islands are actually emerging as inspiring and innovative territories to experiment solutions to reach sustainability. Their role is especially meaningful because this bottom-up approach are positioning small islands as significant actor to propose efficient policy tools, knowledge and action in order to make adaptation effective. The question of energy transition has been viewed in this paper through the prism of potential RES to face the challenge of energy autonomy. The "renewislands" idea was introduced by Chen et al. [8], and their work objective was to define the feasibility of RES penetration in a territory. Several works have examined the potential of RES and the question of energy storage and distribution on small islands [5, 9-13]. Given the vulnerability of small islands to increase in oil prices, it is crucial to have a clear energy policy and documents that could be used as a roadmap to lessen dependence on fossil fuels. Dornan and Shah [14], Prasad et al. [15] underlined the importance of providing tax incentives and having a "Green tax" for the deployment of RES. Shah and Niles[16] explained the importance of clarifying policy (energy and urban planning) for the overall management of a territory. In addition to politics, the characteristics of the territory, such as the size of the territory or demand, are also important. Indeed, it has been found that very small communities with few inhabitants (less than 10,000) facilitate the penetration of renewable energies into the energy mix [17] [18]. For example, El Hierro Island, which has only 10,500 inhabitants in 2015, was able to become self-sufficient in electricity through a wind park - pumped storage combination [19]. On a smaller scale, the island of Tau on Pacific has also achieved self-sufficiency through a combined system of photovoltaic panels and storage. This has provided electricity to some 800 inhabitants of the island of $44 \mathrm{~km}^{2}$ [20].

Reunion Island, our case study, is a French overseas territory located in the Indian Ocean. It covers a 
land area of $2512 \mathrm{~km}^{2}$, its coastline is $207 \mathrm{~km}$ long and its highest peak is $3071 \mathrm{~m}$ above sea level. Reunion is a volcanic island that has a very steep terrain consisting of two volcanic massifs (figure 1). The 870,000 inhabitants on January 1, 2018 (INSEE ${ }^{1}$ data) are located mainly on the coast and the mid-slopes of the island.

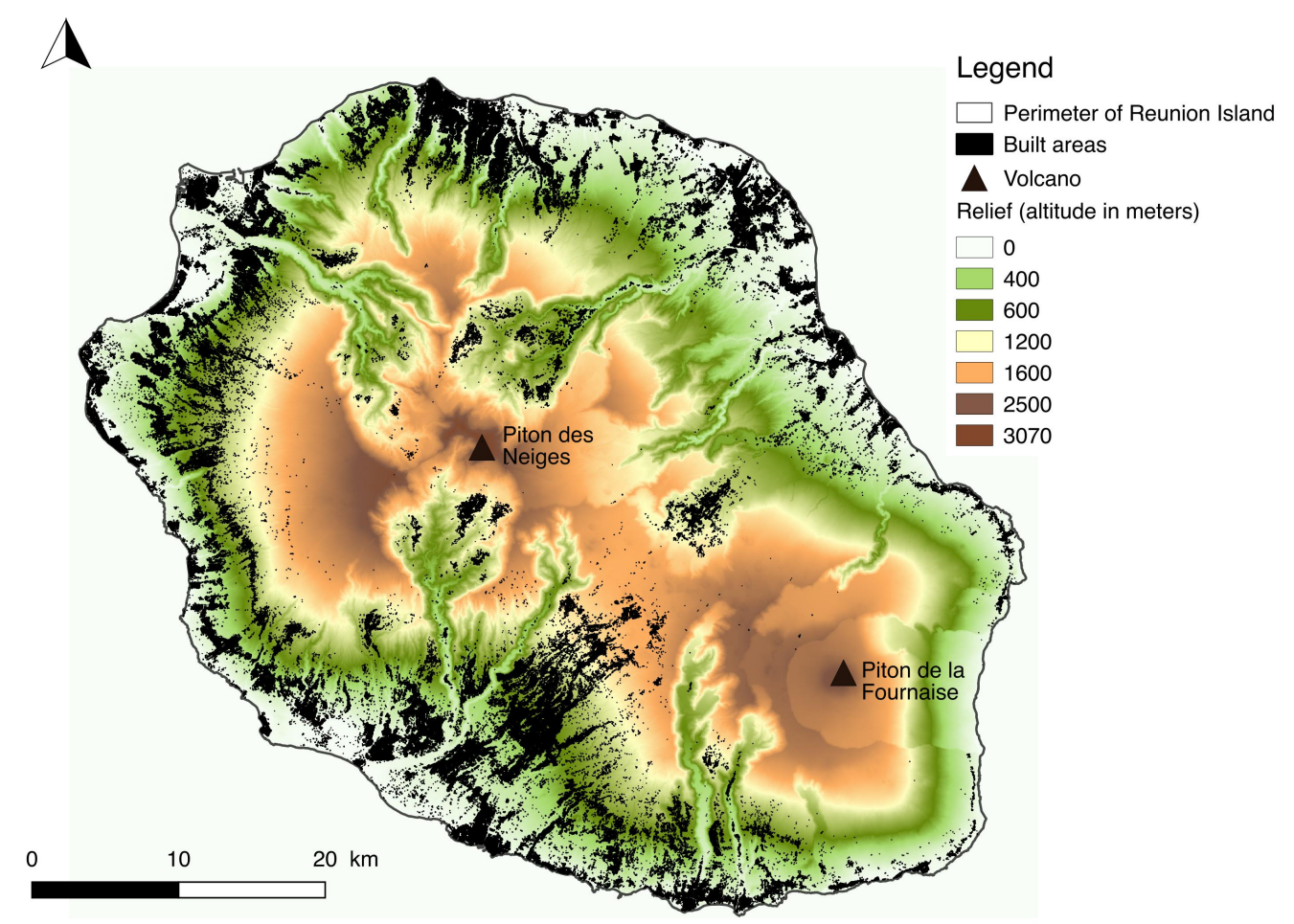

Figure 1: Map of Reunion with indication of Relief and built areas.

Source: Produced under QGIS with IGN2 data

Reunion has plentiful sunshine and a very high potential for several RES, like solar energy, wind energy and hydraulic energy that are already deployed on the island. Since 2000, the Regional Council has chosen to take advantage of these opportunities to reduce the island's reliance on fossil imports. A framework for RES penetration in electricity is being investigated to achieve electricity independence by 2030 . Painuly [21] identified seven major financial, technical, market, social and institutional barriers to the

\footnotetext{
${ }^{1}$ Institut National de la Statistique et des Etudes Economiques

${ }^{2}$ http://www.ign.fr
} 
development of RES. In Reunion, a major problem is the lack of coordination between the energy planning program and its implementation in standard urban planning documents, such as $\mathrm{SAR}^{3} \mathrm{SCOT}^{4} \mathrm{PLU}^{5}$ In this paper, the objective is to discuss an assessment of Reunion's ability to achieve electric self-sufficiency. This discussion will help in understanding the way this overall regional coordination could be enhanced for policymakers. Consequently, the paper is organized as follows: the first part considers the barriers identified for small islands by analyzing the case of Reunion Island; then, an overview of the current energy situation in Reunion is provided; and finally, the energy legislation is detailed, the consideration of energy issue in the planning documents is highlighted, and the implement of these planning documents on the island is analyzed.

\section{Barriers to the deployment of a renewable energy strategy}

Small island territories have been widely recognized by the international community as vulnerable territories, as they are vulnerable to climatic hazards and to the profound changes brought about by the depletion of resources [22]. From small developing states to metropolis-dependent islands, these territories are weakened by their size, remoteness, and many other factors specific to their island characters. Successful energy transitions would thus be particularly favourable for them because they would reduce the current strong inequalities with other continental regions of the world. Successful energy transitions via the decarbonization of the electricity sector are among the major challenges that will face society over the next 25 years, and for islands, this challenge presents the additional issues of development and independence. Seven problems arising from the use of fossil fuels in an island economy were identified in 2001 and include the following: Market failure/imperfection; market distortions; economic and financial issues; institutional issues; technical issues; social, cultural and behavioural issues; and other barriers 2 [21].

This section proposes to review the different categories of barriers identified in these works and to identify the barriers present on Reunion Island.

\subsection{Market failure and imperfection}

This first level of barrier refers to the absence of conditions required for pure and perfect market competition. Among these conditions we can cite in particular the atomicity of the market, which means

\footnotetext{
${ }^{3}$ Schéma d'Aménagement Régional: a regional development plan

${ }^{4}$ Schéma de COhérence Territoriale: an infra-regional development plan

${ }^{5}$ Plan Local d'Urbanisme: a municipal planning document
} 


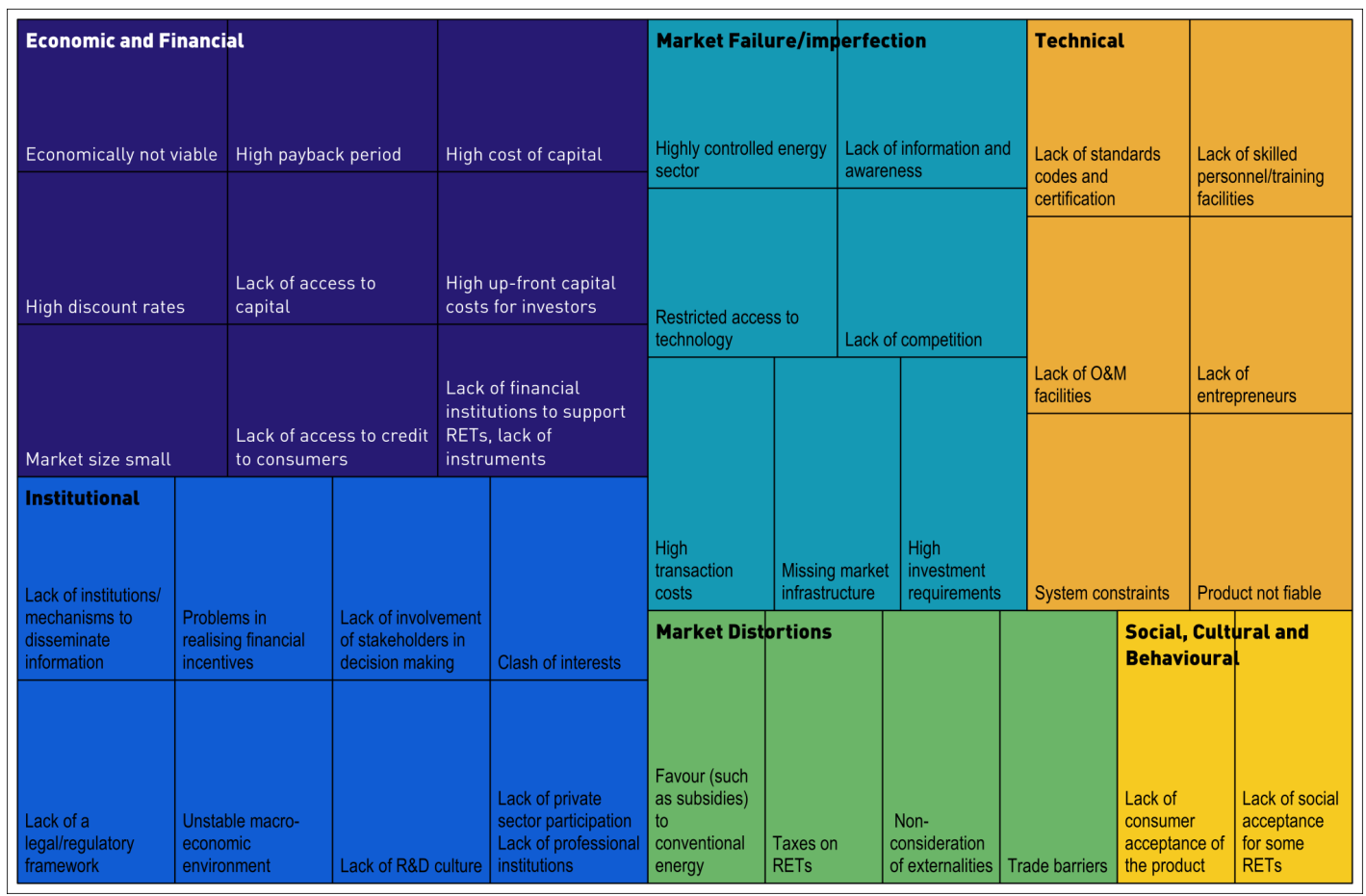

Figure 2: Barriers to renewable energy penetration. Source: [21]

90 that no economic agent has enough weight on the market to be able to control it. We can also mention the homogeneity of the products, which indicates that only the price criterion is preponderant in the differentiation of the products, or free entry into the market, market transparency and mobility of labor and capital production factors.

Applied to the deployment of renewable energies on a territory, these barriers refer to the high control of the energy sector, restricted access to technology, lack of competition and high investment requirements [21]. These barriers are present in the territory of Reunion. The power plant belong to five different entities: public and semi-public with Region Reunion and EDF ${ }^{6}$ and private with Albioma, Veolia and Quadran. EDF is the historical producer and supplier of the island, which gives it a hegemonic place on the market. This limited number of players weakens the market and makes it flawed.

\footnotetext{
${ }^{6}$ Electricité de France: French Electricity Provider
} 


\subsection{Market distortions / Economic and financial barriers}

Through market distortions, Painuly [21] highlighted barriers such as preferences to conventional energy, taxes on Renewable Energy Technologies (RETs), non-consideration of externalities and trade barriers. Overall this is deliberate actions that prevent the perfect competition. In the second half of the twentieth century, Reunion Island has experienced significant population growth; the population tripled between 1950 and 2000. The population is forecasted to reach 1 million inhabitants by 2030 [23]. In the 1980s, the island was nearly self-sufficient in electricity. Indeed, in 1982 the electricity generation was based on $424 \mathrm{GWh}$ of hydropower, 2 GWh of thermal diesel plant. However, an economic boom accompanied by a remarkable population growth forced the island to respond immediately to the growing demand. The fastest way to meet this demand was through fossil fuels. Today, one of the island's objectives is to return to RES while continuing to satisfy demand. Since Reunion has no fossil reserves, $539.2 \mathrm{ktoe}$ of fuel were imported in 2016 for electricity generation. These imports namely coal, diesel oil and heavy fuel oil represent $66 \%$ of the primary sources used for electricity generation.

Economic barriers refer to market size, capital (access and high cost), lack of financial institutions to support RETs, ... The deployment of RES in a territory is costly, and private investment is needed. However, the small size of the market may discourage investment for fear of not being profitable [21]. The financial risk to be borne by an investor is one of the main barriers to the deployment of renewable energy in a territory [24]. In 2013, Reunion had 835,000 inhabitants, 341,000 homes and 75,000 businesses. The market therefore remains small, and there are significant risks in the penetration of new energy production technologies. To facilitate this penetration, the actual risks should be questioned: for example, public authorities could offer incentives to private companies to reduce the extent of the risks they incur.

\subsection{Technical barriers}

Reunion Island has diversified electricity production, with a total of 17 production plants on the island: two oil/diesel plants (34.6\% of the total installed capacity), two coal and bagasse thermal power stations ( $25 \%$ of the total installed capacity), seven hydroelectric power stations ( $15.9 \%$ of the total installed capacity), two wind farms ( $1.8 \%$ of the total installed capacity), three biogas plants $(0.4 \%$ of the total installed capacity), and photovoltaic systems scattered over all municipalities of the island $(22.2 \%$ of the total installed capacity) [25]. These installations, although very diversified, are centralized by EDF and then redistributed via the power grid to consumers. Similar to sustainable neighborhoods, it might be interesting or even necessary to envisage more local production that occurs closer to consumers. The population 
is concentrated on certain parts of the island: $2 / 3$ is localized on the coastal belt. This fact should allow certain facilities to be deployed. Indeed, the upland of Reunion corresponds to the National Park which has been classified in 2009 as world heritage by UNESCO. This area that covers a surface of more than 100,000 ha, that is $40 \%$ of Reunion, could not be use for any renewables plant (except for hydraulic which was already existing). Under several constraint, RETs deployment is restrained at mid levels of the island that allows renewable production which is fairly close to the consumer.

The advantages of decentralized generation and storage technology (DGST) already have been demonstrated [26]: they make it possible to avoid losses due to transport and distribution and thus increase efficiency [27],[28],[29],[30], [31]. They can also reduce $\mathrm{CO}_{2}$ emissions [31],[32],[33] and minimize both damage to health and land use [31].

Production close to the consumer would have another advantage: the proximity of the production system will make consumers more aware of the energy used and the act of consumption. The consumer will have the impression of being a participant, which will help them reflect on their consumption habits [34].

Due to their intermittent nature, some RES such as solar or wind cannot perfectly match the electricity demand. Thus, an energy storage system is necessary to balance supply with demand. Intermittence could be a clear barrier to RES development. Many solutions currently exist, and an overview of energy storage for RES was given by Ould Amrouche et al. [35]. Their main point was that the choice of storage system is driven by applications (e.g., power generation, short term production). In 2015, $10 \%$ of the electricity production on Reunion came from intermittent sources ( $8.5 \%$ for photovoltaic and $1.5 \%$ for wind).

With the PEGASE (Prévision des Energies renouvelables et Garantie Active par le Stockage d'Energie) project, a NaS system of batteries corrects imbalances and supports the frequency of the network, if necessary. This is expected to enable an increase in the share of intermittent RES to $38 \%$ by 2018 . Electricity storage is changing the outlook for RES on the island. A choice must be made for RES electricity production to define the best spatial distribution and type of storage to meet demand. The objective of $38 \%$ is feasible, indeed the share of RES has varied from 34 to 37.8 in the last four years. On may 2018, a 41 MW combustion turbine is initiated. This plant mainly uses bioethanol which locally produced to smooth electricity peak demand. The objective is in medium term to use liquid fuel from algae developed in Reunion. This bioethanol plant will help the mix to rapidly reach to $38 \%$ of RES. A striking example demonstrates the ambitions in terms of technological innovations on the island: a microgrid electrical device was set 
up in Mafate in 2017. Thanks to hydrogen batteries, the electricity system may conserve the energy produced via the photovoltaic installations for several days. This experimental device now supplies three public buildings as a pilot site. If the tests prove conclusive, the device will be extended to individuals (310 families).

\subsection{Institutional barriers}

Institutional barriers can be diverse: a lack of institutions-mechanisms to disseminate information, lack of a legal-regulatory framework, unstable macro-economic environment, lack of stakeholder involvement in decision making, clash of interests, lack of $\mathrm{RD}$ culture, lack of private-sector participation, and lack of professional institutions.

Several crucial point must be considered to challenge energy transition. A fisrt aspect deals with incentive policy through taxes or feed-in-tariffs to encourage RES investment. Another crucial point concerns the social acceptance of RES by the population. The French government has reduced the national feed-in tariff programs for both photovoltaic (PV) and solar water heater (SWH) since 2011. The immediate consequence is the lack of incentive for RES credits for consumers. Thus, private investments have decreased over the last 4 years.

Since the end of the 1990s, more than 141,000 individual solar water heaters (SWH) have been installed on the island, which represents $567,010 \mathrm{~m}^{2}$ of panels. This corresponds to an annual thermal production of 212.6 GWh. This has been helped by a 31\% tax exemption when purchasing a SWH. The consumer rents the equipment for 5 or 10 years, after which they become the owner. At the end of 2015, 38,470 $\mathrm{m}^{2}$ of SWH were in use. Despite the decision of the government to reduce tax credits from $50 \%$ to $30 \%$, SWH systems are supported by RTAADOM 7 The regulation sets the domestic hot water requirements in any new building projects at a minimum of $50 \%$ of SWH. Thus, for SWH, Reunion ranks second in the European Union, behind only Cyprus, with a ratio of $718 \mathrm{~m}^{2} / 1000$ capita.

As shown in figure 3, both SWH and photovoltaic sources are currently stagnating due to the lack of financial support and electricity grid structure. Indeed, to avoid the risk of destabilization of supply-demand balance, the french government has fixed a regulatory limit of intermittent resources penetration at 33\%. Between 1997 and 2006, off-grid PV systems were widely developed. In 2015, four new PV projects were delivered to schools on the island. A significant issue regarding PV in Reunion is that most installations

\footnotetext{
${ }^{7}$ Specific thermal acoustic and ventilation regulations for French overseas regions
} 

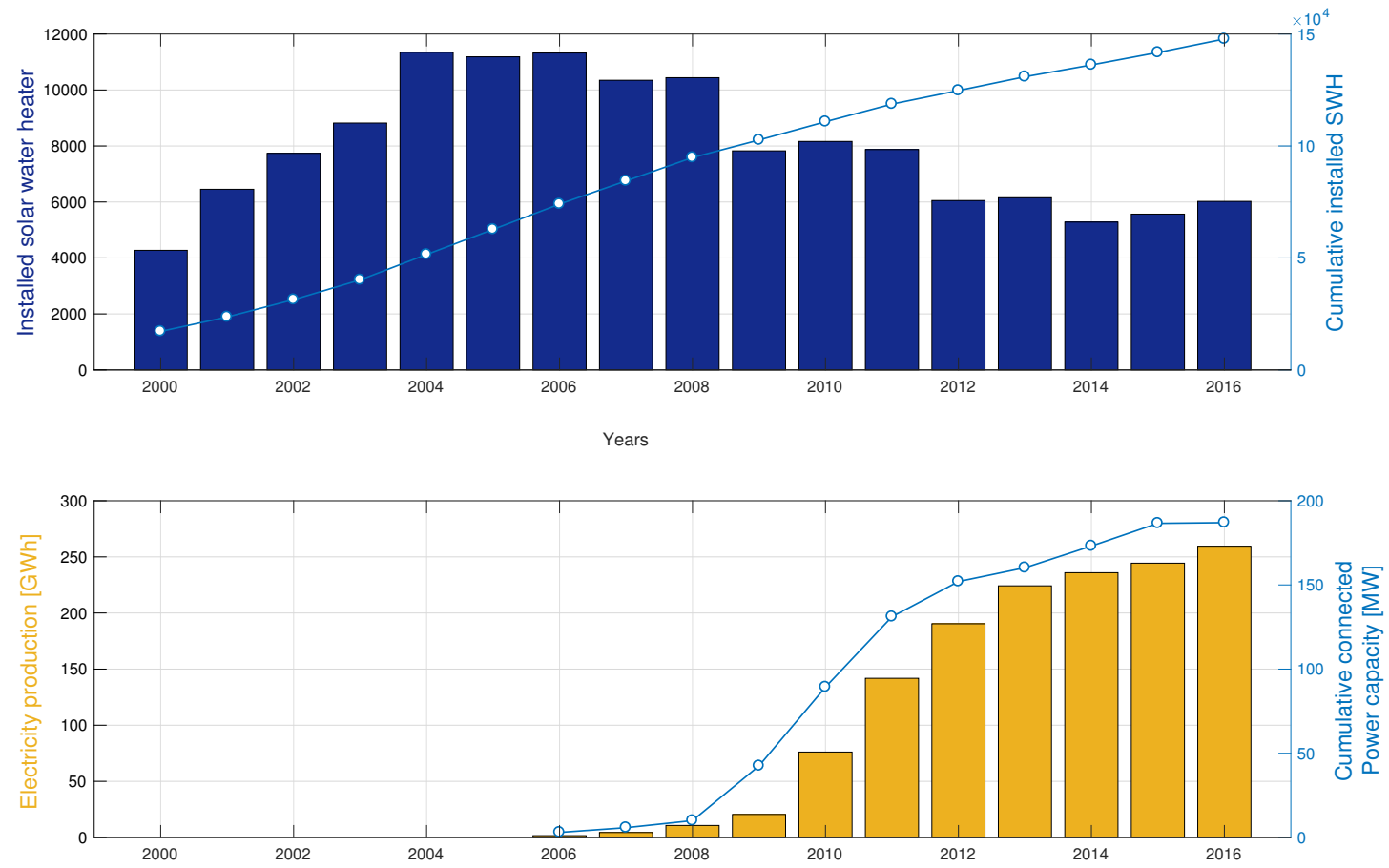

Figure 3: Installed Photovoltaics and Solar Water Heater systems since 2000

are grid connected, which rapidly increased the intermittent electricity rate to 30\% between 2009 and 2012 . Reunion ranks sixth in Europe, with $221.2 \mathrm{~W}_{\mathrm{p}} /$ capita $^{8}$

\subsection{Social, cultural and behavioural barriers}

The social and public acceptance of RES in electricity production could represent a high barrier for energy transitions. The social barriers identified in the reference article are the acceptance of the product and the technology [21]. To achieve this acceptance, local authorities initiated a process in the late 1990s. Reunion Region, through President Paul Vergès, officially launched its insular energy self-sufficiency plan at UNESCO in 1999. The French overseas regions were entrusted with a certain authority in the field of energy planning by the "LOOM' 9 law of 13 December 2000, a strong competence in the field of energy planning. An energy planning program called PRERURE (Plan Régional des Energies Renouvelables et

\footnotetext{
${ }^{8}$ Wp:Watt-peak

${ }^{9}$ Law of orientation for overseas regions
} 
d'Utilisation Rationelle de l'Energie) was launched in 1999 by the Regional Council, [36]. This program provided a pathway to a $100 \%$ renewable energy island and fixed an objective of energy autonomy by 2030 (which also represents the end of the demographic transition).Through its PRERURE plan, the regional council was a national precursor in three areas:

- Energy demand management

- RES penetration

- Sustainable mobility

Actions in favor of the energy transition can be seen through two types of actions: strong aid from the government and other related institutions, and a long-term vision with steps to take for energy independence by 2025 . The aid then took the form of tax credits, bonuses and for the poorest populations, the possibility of renting the devices (SWH and PV) at first and becoming a buyer after a few years. The benefits of this plan can be seen since the 2007-2009 period: a period of about ten years was necessary to change habits of population in areas such as sorting waste, installing solar panels, and building low-energy houses.

Today, the goals of autonomy have been revised:

- energy autonomy by 2030 with a level of 50\% RES in the final consumption of the island in 2020 for the law on the energy transition to green growth (2015) [37];

- electricity autonomy by 2030 for a regional planning scheme: the Regional Climate, Air quality and Energy Plan (SRCAE $\left.{ }^{10}\right)$.

The revised objectives show that there is still action to be taken to achieve electrical or energy autonomy. Among the actions to be carried out with the population, awareness and energy coaching, encouragement of initiatives from community groups, such as urban farming or market gardening, are paths to consider. Building community thinking from the bottom is the best way to gain social acceptance of changes in our territory, [38]. A study have been made in 2017, in Reunion, to understand public acceptance to renewable energy technologies. The survey was carried out of 1,500 inhabitants asking them to give their opinion on several aspects of energy transition for Reunion island. Figure 4 presents the results of the public acceptance to several renewable technologies in their neighbourhood. This study and

\footnotetext{
${ }^{10}$ Schéma Régional Climat Air Energie
} 


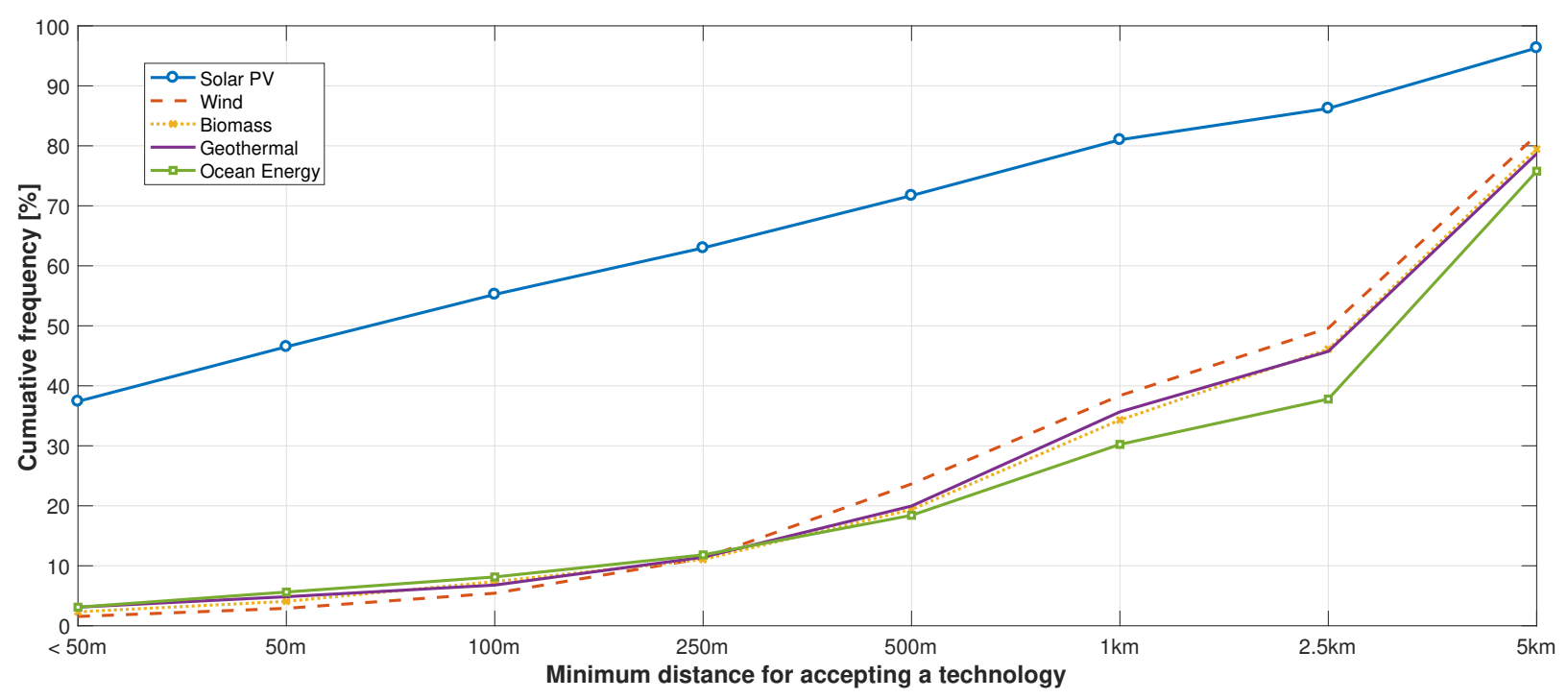

Figure 4: Minimum distances required for the acceptance of renewable energy technologies

approach were similar to those defined in a previous study in Germany, [38],[39]. However, our results significantly differ from their case. According to Fig. 4 around $80 \%$ of participants are accepted renewable technologies at a distance of $5 \mathrm{~km}$. Solar PV is singular as its acceptance is high rapidly reach to $70 \%$ at $500 \mathrm{~m}$

\section{Energy situation of Reunion Island, an outermost region of the European Union}

Energy is crucial for the economic development of any territory. This is particularly true for remote territories such as Reunion. Electricity in Reunion is generated by two independent producers ALBIOMA 11 QUADRAN 12 and the state-owned historical provider EDF. ALBIOMA operates two sugarcane bagassecoal thermal plants which generate $244 \mathrm{GWh},[40]$. Electricity peak demand are ensured by two combustion turbines from EDF, for a total capacity of $120 \mathrm{MW}$. Hydropower represents the first renewable source, its production amounts to $464 \mathrm{GWh}$. One of the most recent RET is biogas plant which are all based mehtanization process. These plants are near three ultimate waste storage site. Biogas only represents $0.58 \%$ (17 GWh) of the total production, for an installed capacity of $4.4 \mathrm{MW}$. Further study actually investigate the possibility to develop gasification in several municipalities.

\footnotetext{
$\sqrt[11]{\text { http: //www.albioma.com }}$

${ }^{12}$ https://WWW.quadran.fr/
} 
In 2016, Reunion's primary energy consumption was 16.6 TWh, $1.1 \%$ higher than the previous year dency on fossils resources is currently $86.6 \%$. We can see that diesel and coal are the main contributors to the energy mix. During the 2000-2016 time period, their contribution has increased from $43.04 \%$ to $55.1 \%$ of the total consumption. This is due to the new thermal power plant built in 2013 and equipped with 12 diesel engines, with a total output of approximately $210 \mathrm{MW}$ [25].
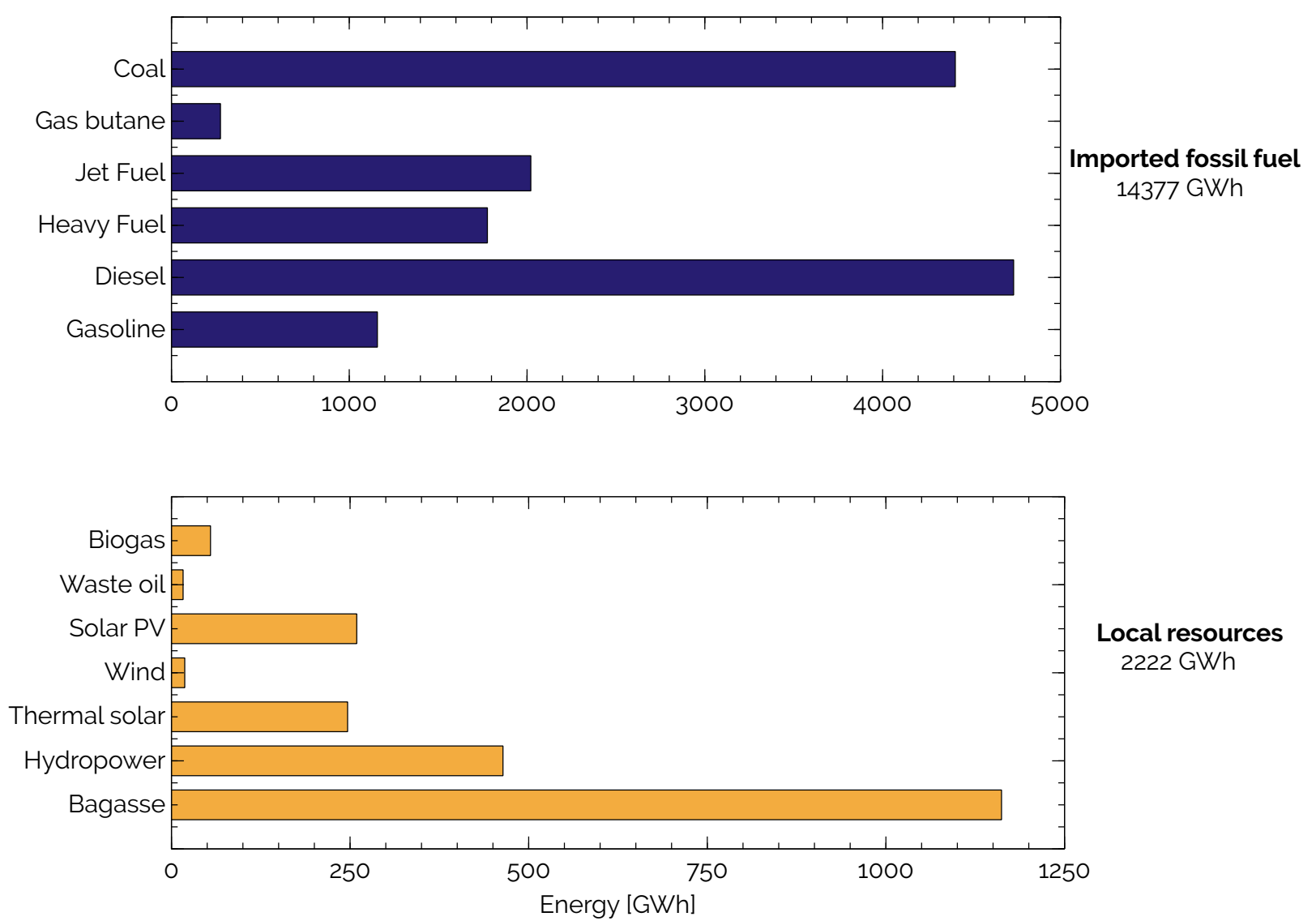

Figure 5: Primary energy consumption for Reunion in 2016

A common feature of small islands is an electricity production that depends heavily on fossil fuel. In 2016, renewable energy accounted for $34.1 \%$ of the electricity production in Reunion, for a total delivered value of $2943.6 \mathrm{GWh}$. One fact that stands out is the instantaneous power of the intermittent energies that reaches the disconnection rate each month. In 2016, the maximum power demand was 481 MW in February. Despite the regional and national incentive policies for renewable energy since 2000, 


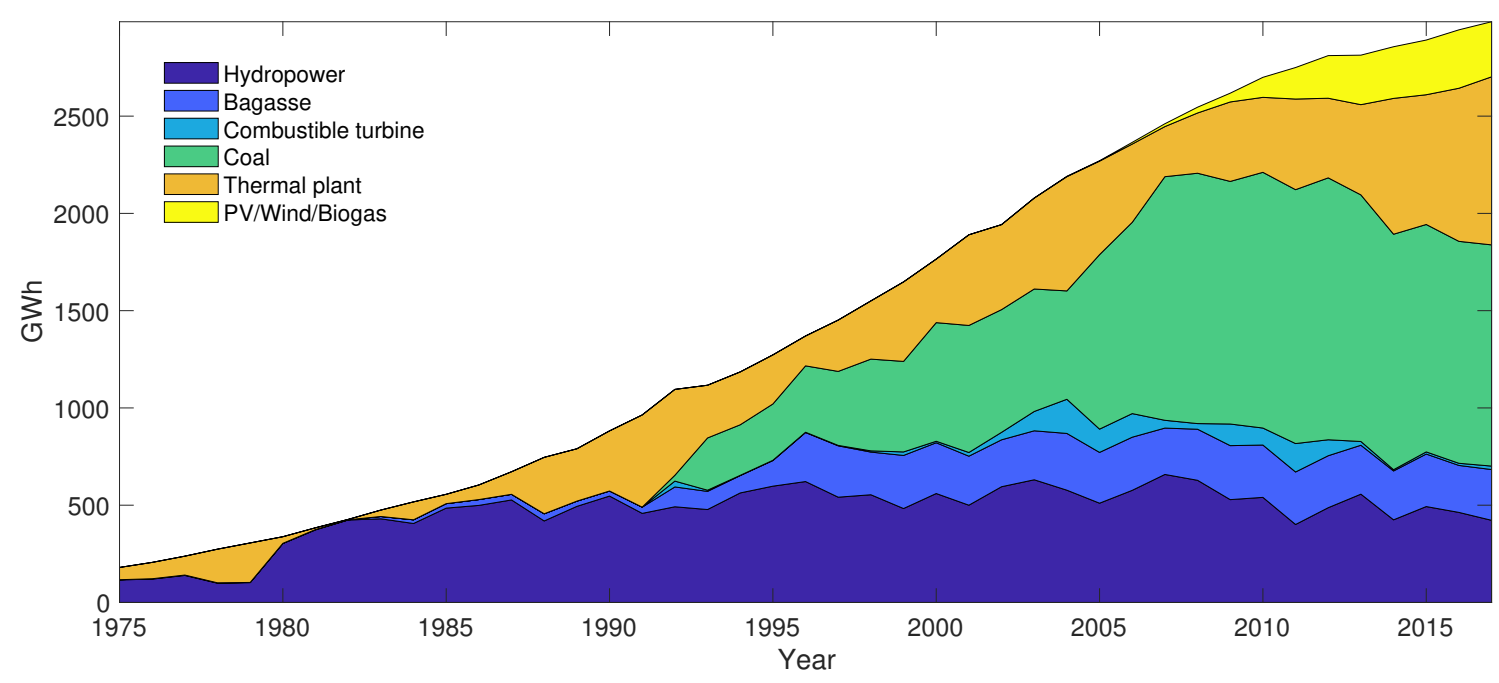

Figure 6: Evolution of electricity generation from 1975 to 2017 overseas department in 1946. The economic benefits of this new status were slow to materialize and came 
in the late 1950s, when the economy began to accelerate. This was a time of intense economic development, profound changes in infrastructures and landscapes, with improvements to the roads, airports and port, and the construction of the Takamaka hydroelectric plant in 1968. This economic development was supported by strong demographic growth. From 1980 to 2000, the annual population rise was 1.9\% (France $0.4 \%$ ), and currently, it is $1.2 \%$ [23]. These historical statistics highlight the necessity of structural changes in electricity production to meet the demand. Until the end of the 1980 s, electricity was produced by five hydroelectric plants; the island was $100 \%$ renewable. Hydropower is still the most important RES. The second main RES is photovoltaic systems. Production increased from 1.6 to 244.4 GWh from 2006 to 2015. This growth is constrained by a structural safe threshold that was initially set by the government at $30 \%$, [46]. This limit is necessary due to the intermittent and unpredictable nature of photovoltaic systems. The level has increased to $33 \%$ owing to the higher storage capacity installed in 2015 . Reunion has other RES, such as solar thermal, biogas, wind, wave and geothermal. This potential and possible scenario for 2030 is detailed in several studies: [41], [47], [36]. These studies confirm that it is possible for Reunion to be self-sufficient using RES.

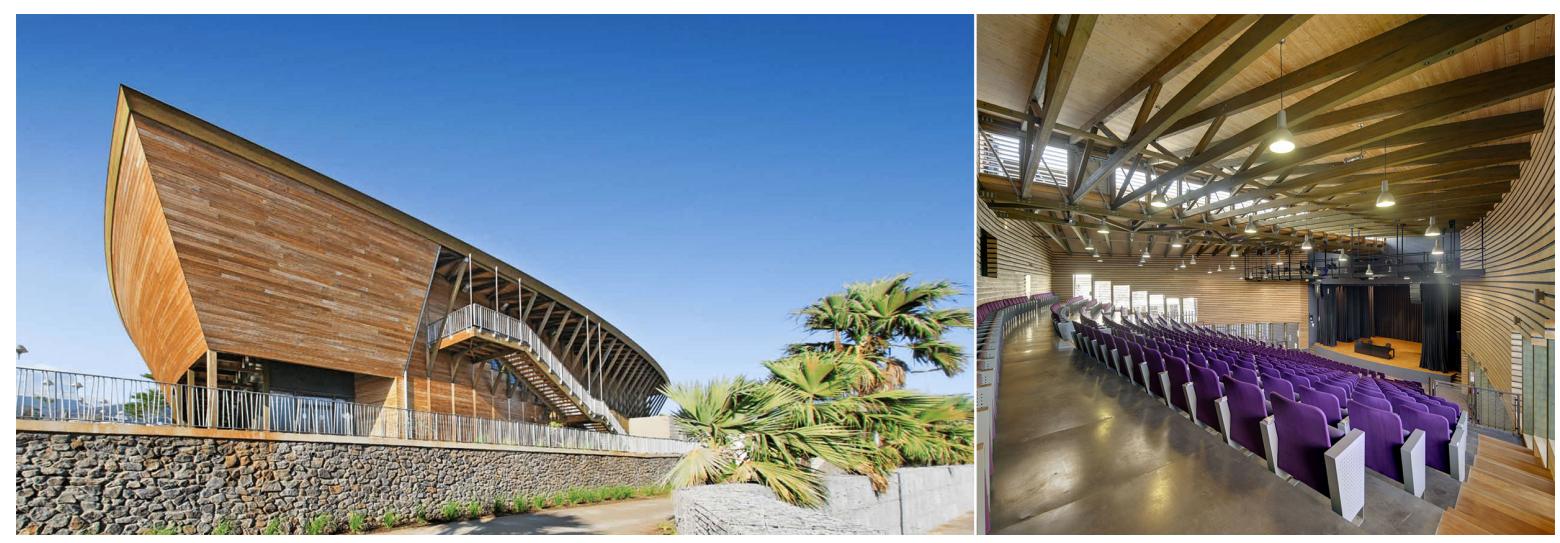

Figure 7: First natural ventilation based bioclimatic amphitheater under tropical climate.

Energy management is another key area being investigated by ADEME ${ }^{13}$ EDF and policymakers to assist in Reunion's energy transition. The action taken over the past 15 years has fundamentally changed consumer behaviour. The demand has slowed for 15 years, which has allowed us to limit the needs for new power plants. A key indicator is the fact that annual growth in electricity production has decreased

\footnotetext{
${ }^{13}$ The French Environment and Energy Management Agency
} 
from $7.8 \%$ in 2000 to $1.8 \%$ in 2016. Specific thermal regulations for overseas departments have been created to limit electricity consumption and enhance thermal and acoustic comfort [48]. These regulations have forced the development of low-energy buildings, new urban regeneration projects, and an extensive use of natural ventilation. In 2015, The University of la Reunion built the first bioclimatic lecture theatre with 550 seats (see Figure 7), and it does not use any cooling systems. Only passive solutions were considered, including innovative natural ventilation architecture and solar protection. The building's electricity consumption is currently $28 \mathrm{kWh} / \mathrm{m}^{2}$ per year, which is five times less than the energy used by a conventional lecture theatre.

Over the last decade, the energy management plan has allowed electricity consumption to decrease to 1.43

MWh per capita; in France, the value is 6.95, and that of a similar island, such as Mauritius, is 2.18 [49].

\section{Energy planning}

This section proposes the identification of the different levels of energy regulation (laws and planning documents) and their implementation on Reunion.

\subsection{The legislative framework: the guideline}

Reunion's legislative framework can be understood through three levels of elements:

- the international framework since France participates in the United Nations International Climate Conference;

- the European framework since France belongs to the European Union;

- the French legislative framework with a series of laws committed to the energetic cause.

The European Union and international framework is rich and drawing a comprehensive picture is not easy. We therefore decide to address some key dates that have marked French politics. We then propose an analysis of the French laws in four points.

Since the Earth Summit in Rio in 1992, the United Nations meets every year around a conference on climate change called the Conference of the Parties (COP). It was during these conferences that the famous Kyoto Protocol and the Paris Agreement were signed. These conferences and agreements are not unanimous on the international scene, but they are high places of exchange and debate that highlight the consequences of global warming. The United Nations Conference on Climate Change COP15, was held in 
Copenhagen in 2009. The summit, often called the "summit of shame", reached an agreement among the major countries of the world - the US, China, India, Brazil and the European Union - to engage in a common battle against climate change by agreeing to limit any future temperature increase to $2^{\circ} \mathrm{C}$, according to the scientific recommendations of the IPCC (Intergovernmental Panel on Climate Change). COP15 was criticized because of the ambiguous nature of the agreements reached. Nevertheless, France has a desire to show good faith and is campaigning actively for a reduction in emissions between $25 \%$ and $40 \%$ in developed countries by 2020 and a reduction of $50 \%$ in global emissions by 2050 . In 2015, during the COP21 held in Paris, the 195 countries present sign the Paris Agreements. Among the many objectives are the global cap of greenhouse gas emissions as soon as possible. In 2017, the United States decided to withdraw from these agreements, which caused an international outcry but was not enough to call into question the commitment of other countries, such as countries of European Union.

The European Union energy policy can be summarized in three main areas. First is the issue of energy security, which promotes a diversification of supply sources to limit the overall vulnerability. Second is the issue of environmental objectives (e.g., Kyoto Protocol targets, program objectives of Europe 2020). This second point is focused specifically on energy efficiency, the integration of renewable energy into the network, and the development of smart grids. The final area concerns the economic competitiveness of the energy sector (e.g., market liberalization, affordability)[50].

Europe has, since 2008, committed to an Energy-Climate Change Package, which is a legislative instrument dedicated to increasing energy efficiency and the use of renewable energy and reducing greenhouse gas emissions. The initial objective year was 2020. In 2014, these objectives were revised to reach maturity in 2030. It was under the French management that this legislative package was adopted for the first time. France has been committed to the Kyoto Protocol targets since 2004, when its first national climate plan was introduced. As part of the Kyoto Protocol, France has set a target of stabilizing its greenhouse gas emissions over the period 2008-2012 compared to the 1990 levels. Its first national climate plan was introduced in 2004 and, for the first time, included measures to reduce carbon emissions in all sectors of the economy and daily life to stabilize carbon emissions to the 1990 levels by 2010, that is to say 560 million tonnes of carbon dioxide equivalent. It also stipulated a four-fold reduction in emissions by 2050.

In France, a particularity is the public character of energy policy. This ensures the strategic inde- 
pendence of the nation and promotes economic competitiveness and is based on the maintenance and development of national and local public enterprises in the energy sector. The energy is indeed considered a need in the general interest. A major issue is the territorial coherence and connection between the various administrative levels of the territory. Analyzing the effectiveness of French energy policies and the success of their application on the territory is not easy. To analyze French laws, we propose to identify four points that interest us particularly. (Table 1 :

- the fight against global warming (GW);

- the promotion of renewable energies to change the energy mix (RES);

- demand side management (DSM);

- the proposal of planning tools for anchoring to the territory $(\mathrm{P})$.

Four laws over 10 years were selected for the analysis: the Energy Program Act of 13 July 2005 (POPE), the Law 2009-967 of 3 August 2009 (Grenelle 1), the Law 2010-788 of 12 July 2010 (Grenelle 2), the Law 2015-992 of 17 August 2015 on the energy transition for green growth (LTEPCV). The laws Grenelle 1 and Grenelle 2 are presented together (Table 1 .

Indeed, the question of the energy transition has been brought by the global alert of the consequences of global warming. This energy transition involves the integration of renewable energies instead of fossil fuels, which is accompanied by energy management. Finally, the application to the territory shows the connection between the political will and the local context.

The analysis of the first three criteria (GW, RES, DSM) makes it possible to show that the objectives are maintained over time: little evolution in terms of thresholds, but a firm reaffirmation with each new text. Regarding the last criterion $(\mathrm{P})$, the Urban Planning Code is constantly completed with each new text, which shows the close link between urban planning and energy planning. This link is confirmed by the different territorial planning plans created by these laws, like the PCET ${ }^{14}$ or the SRCAE. The criteria chosen to analyze these texts are not exhaustive and the richness of these laws is not completely highlighted. Therefore, the following paragraphs will attempt to provide additional information. For easier reading, we take again the diminutive POPE, Grenelle 1 and 2 and LTEPCV used previously.

${ }^{14}$ Plan Climat Energie Territoire 
Table 1: Analysis of four French energy laws from 2005 to 2015

\begin{tabular}{|c|c|c|c|c|}
\hline & GW & RES & DSM & $\mathbf{P}$ \\
\hline $\begin{array}{c}\text { POPE } \\
2005\end{array}$ & $\begin{array}{l}\text { "To reduce average annual greenhouse } \\
\text { gas emissions by } 3 \% \text { per year. } \\
\text { "Goal of dividing by four global emissions } \\
\text { of greenhouse gases by } 2050 .\end{array}$ & $\begin{array}{l}\text { *To meet } 10 \% \text { of France's energy needs } \\
\text { from renewable energy sources } \\
\text { (including } 21 \% \text { of electricity needs) } \\
\text { by } 2010 .\end{array}$ & $\begin{array}{l}{ }^{*} \text { To bring the annual rate of decline of } \\
\text { final energy intensity to } 2 \% \text { in } 2015 \\
\text { and } 2.5 \% \text { in } 2030 \text {. }\end{array}$ & $\begin{array}{l}\text { "Urban Planning Code is completed and rules } \\
\text { of the PLU are modified (for example, the } \\
\text { possibility of extending the land load factor } \\
\text { if a building is of high energy performance). } \\
\text { "Proposal of Climate Plan. }\end{array}$ \\
\hline $\begin{array}{l}\text { Grenelle } 1 \text { and } 2 \\
\quad 2009 \\
2010\end{array}$ & $\begin{array}{l}\text { *Same goals with precision: In } 2050 \text {, reduce } \\
\text { annual greenhouse gas emissions to less than } \\
140 \text { million tonnes of carbon dioxide equivalent. }\end{array}$ & $\begin{array}{l}\text { "To increase the share of renewable energy } \\
\text { to at least } 23 \% \text { of final energy consumption } \\
\text { by } 2020 .\end{array}$ & ${ }^{*}$ Mentioned but no numerical targets & $\begin{array}{l}\text { "Urban Planning Code is completed and rules of } \\
\text { the PLU are modified. } \\
\text { "The link between the different planning } \\
\text { documents of the territory is clarified and } \\
\text { their sustainable development goals reaffirmed. } \\
\text { "Territories (regions, departments, municipalities } \\
\text { and groups of municipalities) of more than } 50,000 \\
\text { inhabitants are encouraged to establish Territorial } \\
\text { Climate Energy Plan (PCET). } \\
\text { "Creation of a regional renewable energy plan } \\
\text { for each region. }\end{array}$ \\
\hline $\begin{array}{c}\text { LTEPCV } \\
2015\end{array}$ & $\begin{array}{l}\text { "Reduce greenhouse gas emissions by } 40 \% \\
\text { between } 1990 \text { and } 2030 \text { and divide by four } \\
\text { greenhouse gas emissions between } 1990 \text { and } \\
2050 .\end{array}$ & $\begin{array}{l}{ }^{*} \text { To increase the share of renewable energies } \\
\text { to } 23 \% \text { of gross final energy consumption in } \\
2020 \text { and } 32 \% \text { of this consumption in } 2030 \text {. } \\
\text { "In } 2030 \text {, renewable energies must account } \\
\text { for } 40 \% \text { of electricity production, } 38 \% \text { of } \\
\text { final heat consumption, } 15 \% \text { of final fuel } \\
\text { consumption and } 10 \% \text { of gas consumption. }\end{array}$ & $\begin{array}{l}\text { *To reduce the final energy consumption } \\
\text { by } 50 \% \text { in } 2050 \text { compared to the reference } \\
2012 \text {, aiming at an intermediate objective } \\
\text { of } 20 \% \text { in } 2030 .\end{array}$ & $\begin{array}{l}\text { "Urban Planning Code is completed and details are } \\
\text { given on the different planning documents such } \\
\text { as the PLU. } \\
\text { "Creation of "positive energy territories". }\end{array}$ \\
\hline
\end{tabular}

The POPE established France's energy policy priorities [51] and has made climate change a priority in energy policy. The energy question is treated in 4 points: national energy strategy, demand side management, renewable energy and direction of French energy policy. The demand side management comes in several levels: energy-saving certificates, local communities, energy management in buildings and consumer information to enable transparency and personal awareness. Renewable energy should be integrated into housing. The strategic direction taken by France can be summarized in two main areas: first, it is well organized and ensures consistency between the different policy levels (local-nationalEuropean), and second, it ensures the diversification of the energy supply (maintenance of nuclear power and promotion of renewable energy)[52]. This law has given rise to the Territorial Climate Energy Plan (PCET), which are territorial sustainable development projects whose purpose is to combat climate change and encourage adaptation planning. The intended result is a resilient and robust country that benefits its population and activities.

These voluntary approaches are at the initiative of local authorities. The PCET is a framework of strategies at different territory levels to control energy consumption, increase green production and reduce emissions. This first version of the PCET remains a non-binding approach for communities. Following that 2005 law, France is developing a "climate plan" that is updated every two years with national measures 
to combat climate change. This plan allowed the transposition of European directives in 2006. Priority sectors include construction and transportation. It combines regulatory, tax and incentive measures to limit the energy consumption of these two sectors and promote RES.

In 2009 and 2010 France adopted Grenelle 1 and Grenelle 2 relating to the implementation of the Grenelle Environment Act. The Act lists a series of measures to implement the 273 Grenelle environmental commitments (a consultation involving various major actors in the territory), held from July to October 2007. These measures include combating climate change, protecting biodiversity and the natural environment and risk prevention for environment and health [53]. In addition to the classic measures to combat global warming, this law clearly links planning and energy by promoting renewable energies in the Urban Planning Code [52].

Grenelle 2 requires developing PCET for local communities of more than 50,000 inhabitants. This takes over from the SRCAE. This document contains the guidelines of European directives on climate and energy at the regional level. This scheme sets out broad guidelines for reducing energy consumption and preventing greenhouse gas emissions. It is based primarily on an inventory of emissions of greenhouse gases and chemical pollutants and on a balance sheet of energy production at the regional level. This scheme must then determine objectives for 2020 and 2050 to curb climate change, mitigate its impact, adapt to reduce air pollution and set objectives to enhance the use of renewable energies.

In view of Climate Change Conference (COP21) held in Paris in late 2015, France voted on LTEPCV in August 2015. In roughly two hundred articles, the law aims to strengthen the fight against climate change and reinforce energy independence by better balancing various supply sources. The measures envisaged are varied with, for example, the renovation of buildings (renovate energetically 500,000 units per year from 2017, of which at least half is from low-income households). Another aim is to reduce fuel poverty by $15 \%$ by 2020 [37].

This law has created a label for territories in an energy transition: "Territoire à Energie Positive pour la Croissance Verte" that means "Territory in Positive Energy for Green Growth" (TEPCV). The objective is to give an area an impulse to favor a commitment to environmental excellence. A call for proposals was launched in France in 2015, and of 500 candidacies, 212 territories winners won the TEPCV label. These territories are committed to a program of measures to achieve the following objectives: reduction of energy consumption in buildings, reduction of greenhouse gas emissions in transport, more sustainable waste management, development of renewable energy, preservation of biodiversity, environmental 
education and citizen participation. In Reunion Island, three territories were awarded the label: CIVIS (Communauté Intercommunale des VIlles Solidaires), CIREST (Communauté InteRcommunale de l'EST) and TCO (Territoires de la Côte Ouest) (see Figure 8] [54].

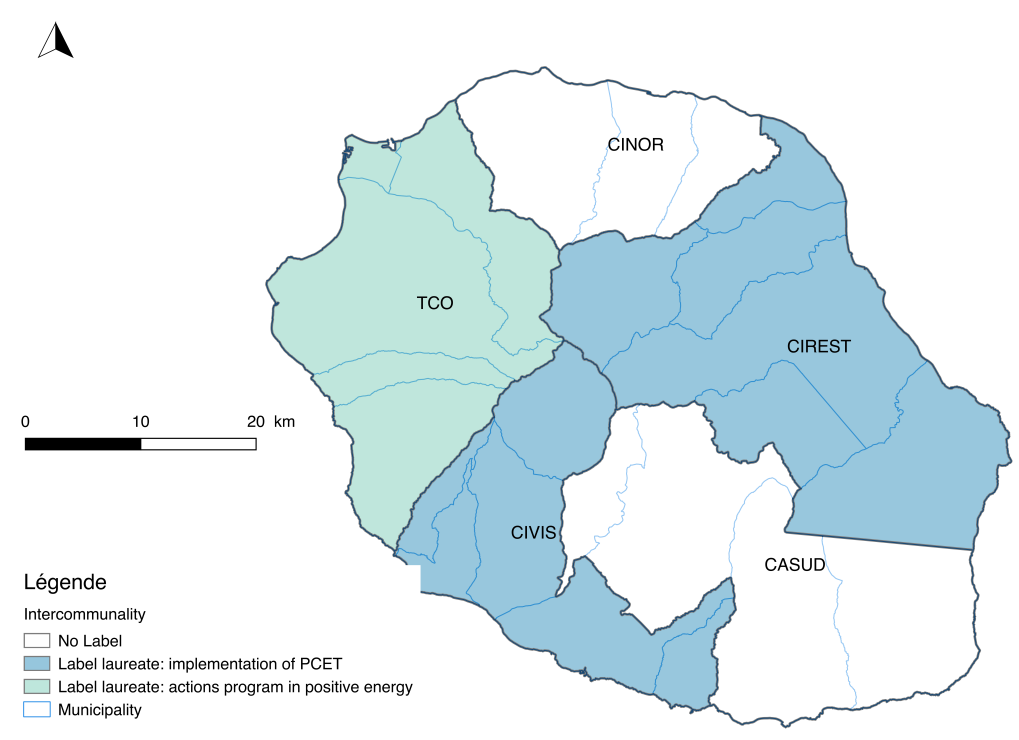

Figure 8: The TEPCV (Territoire à Energie Positive pour la Croissance Verte) laureate of Reunion Island

\subsection{Planning document and energy planning}

For an application to the territory, the various laws and their principles previously seen are translated into urban planning documents and energy planning documents that bring a local dimension.

\subsubsection{The connections between documents: different possibilities}

There are different urban planning documents according to the different scales of application. Their prerogatives are different but there is a close link between these different documents. Article L. 111-1-1 of The Urban Planning Code introduces a hierarchy between the different planning documents according to their relations with each other: compliance or compatibility. The concept of compatibility differs from compliance with the doctrine and jurisprudence by their level of requirements. A compliance relationship is more demanding than compatibility, which requires that the provisions of a document do not hinder the application of the provisions of the higher ranking document. Compliance will apply among the law, the Town Planning Code and planning documents. They must strictly observe the rule of law included 
in legislative documents and the Town Planning Code. Similarly, this conformity will exist between the planning documents and planning permission: planning permission must, for example, be in accordance with the PLU. By contrast, there is compatibility between the different planning documents. The lower ranking document must be compatible with the higher ranking document.

A third type of relationship can be identified between planning documents; in addition to documents for which a compatibility report is required, the Urban Planning Code stipulates that planning documents must consider a number of other plans and programs, i.e., not ignoring the general objectives of another document. This is the case for PCET and SRCAE on SCOT (Territorial COherence Scheme) or PLU Local Urbanism Plan (in the absence of SCOT).

\subsubsection{Overseas region: the three level planning}

In overseas regions, there are three main planning documents around which many other documents revolve (see Figure 9). Each lower ranking document must be compatible with the higher ranking document. Around these three documents are the PCET and SRCAE, among others. We describe hereafter only those documents in which we can identify provisions on energy policy.

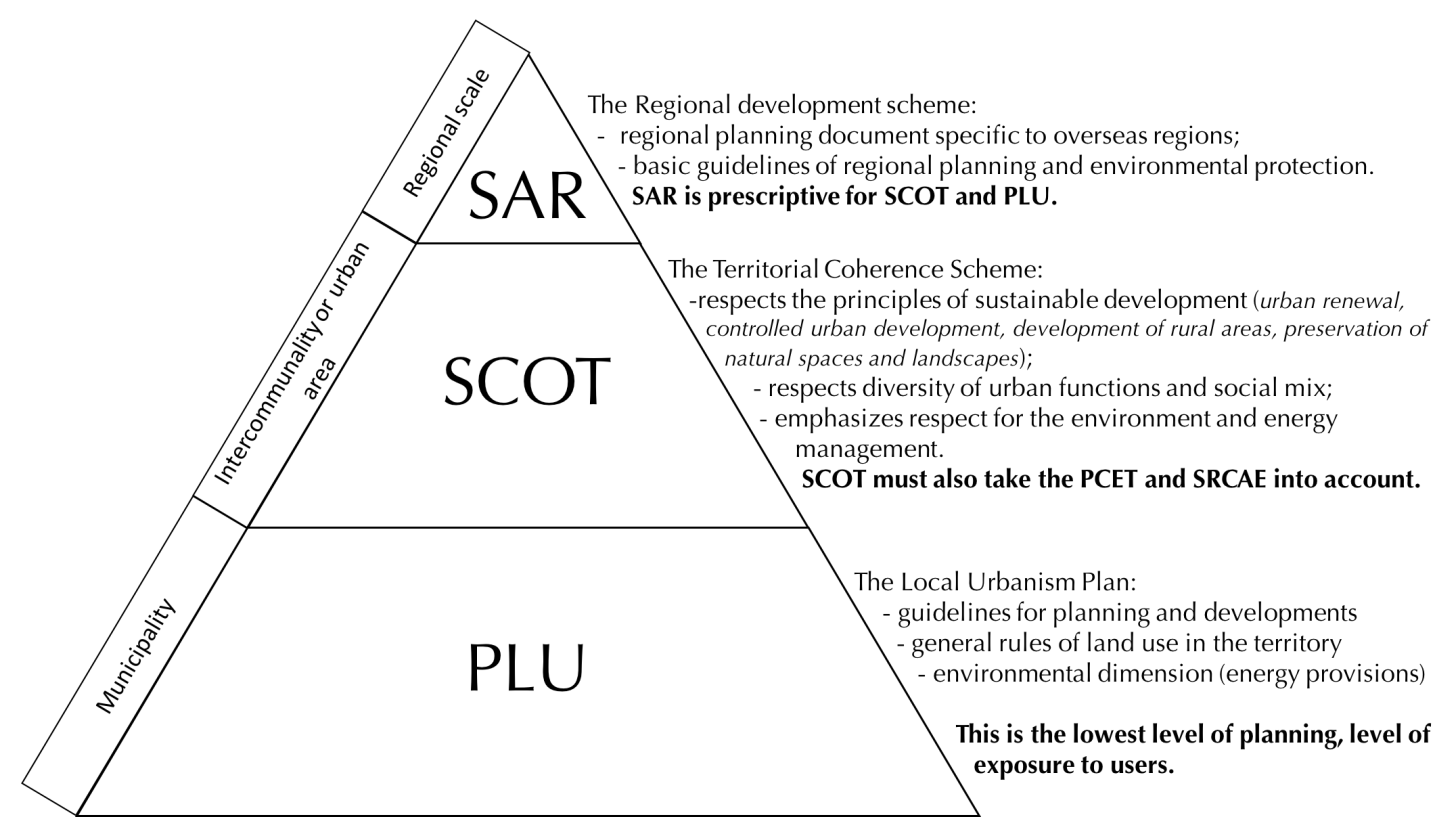

Figure 9: Hierarchy of main planning documents on overseas regions

The SAR includes an important environmental dimension. For example, the SAR of La Reunion, approved in 1995 and revised in 2011, aims to reconcile population growth (1 million people expected on the 
island by 2030), housing, urban infrastructure and jobs needs while preserving the natural and agricultural territorial capital. We can see sustainable development reflected through these objectives.

Reunion's SAR has four main development priorities, including the protection of natural and agricultural areas, the anticipation of climate change by densifying the territory for the better management of water networks, and the prioritization of basic large-scale energy projects. The document stipulates a reduction in the share of fossil fuels in energy independence as a major environmental issue for the island. At regional level, the political commitment to the energy transition is clearly stipulated.

At the scale below, we find the SCOT. This strategic document has a large sustainable dimension that is visible in the structuring of its composition documents:

- a presentation report, which contains a diagnosis and an environmental assessment

- a development and sustainable development plan (PADD)

- an orientation and objectives document (DOO), which is effective against the PLU, PLH, PDU and all municipal planning documents as well as major development operations (ZAD (designated development area), ZAC (joint development zone), etc.).

A sustainable dimension is also visible on the PLU, which is the document on the finest scale. PLU documents include PADD and OAP (Orientation d'Aménagement et de Programmation), which is respectively a sustainable development plan and some planning and programming guidelines. These documents have an environmental dimension by creating energy provisions. Article L121-1 of Urban Planning Code authorizes the PLU to identify the conditions for ensuring the production of renewable energy. To do this, the PLU has leverage to impose better energy and environmental performance. It cannot, however, impose the use of a renewable energy source. It can nevertheless integrate the requirements to ensure a proper architectural integration of thermal and photovoltaic solar panels with the surrounding environment [55]. In Article 11.1, the PLU of Saint-Leu indicates that buildings' roofs must provide for the implementation of solar panels to produce hot water or photovoltaic electricity, under the optimum orientation conditions, slope and architectural integration [56]. Article L 128-1 of the Urban Planning Code provides for a bonus of up to $30 \%$ through the PLU (land use coefficient) for constructions satisfying high energy performance criteria or fed from equipment for renewable energy production or recovery [55]. Designated at the municipal and inter-municipal levels, the PLU is the urban planning document at the finest scale. Any project subject to planning permission (construction license, conversion permit, preliminary declaration of work, 
and demolition permit) must respect PLU requirements.

\subsection{Advances in planning in Reunion Island: a difficult pace to follow}

In Reunion Island, urban planning documents, similar to the economy of the island, suffer from delays in the progress of French legislation in this field. For example, for the smallest scale (municipal), planning document, the PLU, only 8 of the 24 municipalities have a valid PLU in force. Of the remaining $16 \mathrm{mu}$ nicipalities, half still use the PO\$ ${ }^{15}$, and the rest have a PLU under revision (revision made useful by new legislation or revision of a higher ranking document such as the SAR in 2011) (see Figure 10p.

Of the five intercommunalities, four SCOTs are required, but only two intercommunalities have a SCOT in force. Another intercommunality is currently revising its SCOT following the SAR review in 2011. The other one is currently being studied. The PCETs concern all the intermunicipalities in Reunion, but among them, only three are currently operative. It should be noted that the CIVIS has obtained the TEPCV label for the implementation of its own PCET.

On a regional scale, the Reunion SAR was revised in 2011, and the SRCAE was improved in 2012. From a regional perspective, strategic guidelines exist. However, documents lag behind at smaller scales. Consequently, at the level of the urban project in Reunion, the urban planning documents to be considered will not necessarily account for new environmental and energy concerns because the documents in force do not mention these new considerations. This is a kind of "urbanistic void" (similar to the notion of legal void).

\footnotetext{
${ }^{15}$ Plan d'Occupation des Sols, previous version of the PLU
} 
$1 \mathrm{SAR}$

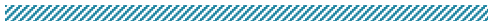
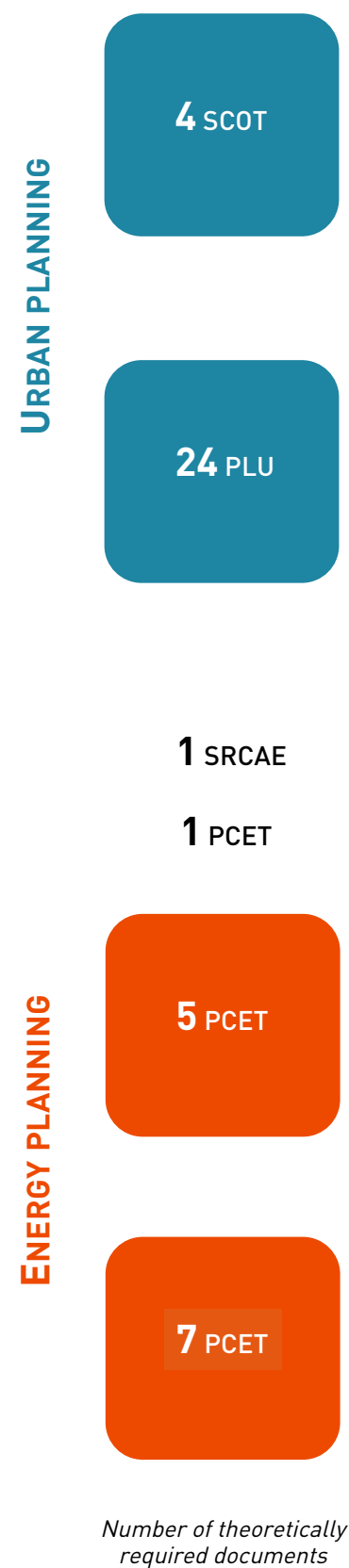

REGION

1 SAR since 1995 - revised in 2011

DEPARTEMENT

GROUP OF MUNICIPALITIES
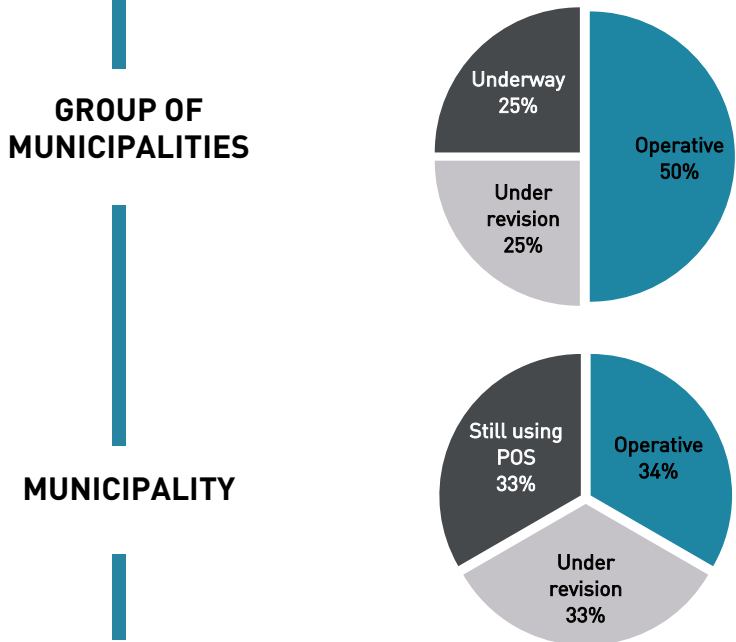

1 SRCAE (2013)

1 PCET (2014)

DEPARTEMENT

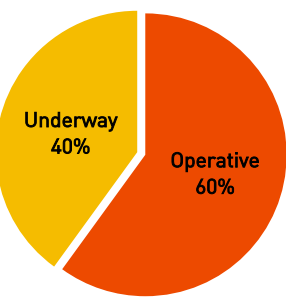

MUNICIPALITIES

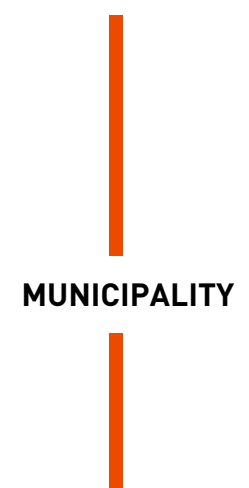

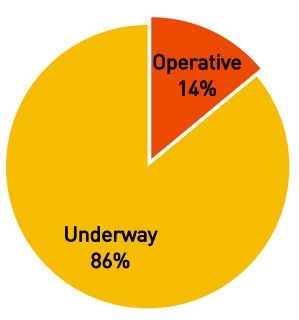

Status of documents

Figure 10: Documents prescribed by law and documents currently operative.

The figure 10 demonstrates that the island is not up to date in the deployment of planning documents. 
The multitude of scales and inevitable delays in updating ultimately impede the implementation of territory projects. Legislation and normative documents relating to the question of energy are numerous in Reunion, as French territory. Nevertheless, this legislation has produced a multitude of documents, each corresponding to a precise scale. On Reunion, all these documents are not yet implemented. While some parts of the territory are following developments, like the CIREST, TCO and CIVIS that followed the appearance of the TEPCV, other parts of the territory are lagging behind. As shown in figure 10 it is at the finer scales that the documents are late: on the scales of groups of municipalities and municipalities. There is also a distinction between pure urban planning documents and energy planning documents: urban planning documents are more widely deployed than energy planning documents. But since the energy issue is dealt with in urban planning documents, it is not the energy question that must be questioned. Rather, it is the lack of resources for implementation, or perhaps even the lack of clarity, for the communities in charge of implementation. It is a real possibility that this multitude of documents hinders implementation. An urban project implemented in a specific region will have to respect a certain number of documents, but these documents will not always be up to date and may occasionally be obsolete.

\section{Conclusion and policy implications}

This paper examines France's energy policy and its implications for the planning documents that have inherited an energy planning issue. Reunion Island, a French overseas region, was able to deploy a incentive legislative package, particularly regarding its commitment to energy efficiency and renewable energy. This commitment represents big strategic developments in French territories. It requires the support of planning and urban development documents to integrate energy issues into the planning stages. Small islands are actually more and more considered as land of opportunities to investigate sustainable solutions to face the effects of climate change. This paper also explores the great diversity of legislative packages and their translation into planning documents. A multitude of measures and scale can complicate the single objective: to make energy transition successful. Political commitment is real. In practice, there has been a delay in Reunion in measure implementation, particularly through planning documents. Of the twenty-four municipalities that make up the island, in 2016, 8 had still not approved their Land Use Plans (scale directly above urban project). The legislative and policy frameworks seems to be not sufficient to achieve the energy transition on Reunion Island. This paper also presents the island's energy mix and highlights its potential. History has shown the strong desire of the island to use RES and energy manage- 
ment. Reunion was almost energy self-sufficient in the 1980s because of its hydroelectric power stations. Similar to many islands, Reunion has real potential for the development of renewable energy, but the large population growth has relegated energy concerns to the background of the island's development concerns. Energy is becoming a secondary concern for the development of the island. Population growth has made it necessary to import fossil fuels to meet the growing demand. Reunion, however, has strong potential for the development of RES, particularly, hydroelectric, biogas, photovoltaic, solar thermal, wind, ocean energy and geothermal. This slowdown is structural because it is not visible in the policies or the commitment of the research and development sector, where the will to make energy transitions successful is clearly highlighted. In the next few years, the island must be able to both absorb the growing population and successfully engage in energy transitions. Thus, the current model of development is unsuitable and urban planning and urban projects (notably urban renewal) need revising, including new practices (energy consumption and production).

RES deployment in Reunion Island is linked closely to incentives. This deployment goes through mechanisms, such as the Feed-In Tariffs (FiT) or green bonds ..., which place RES outside the electricity market and guarantees producers stable tariffs over most of the lifetime of their system. This mechanism has been progressively removed by the government on Reunion Island. However, due to the small size of the island market, it is important to have financial support from the government. More generally, renewable energy is experiencing progressive investment, with an increase in investment according to the interests of the investors involved. A key point is to find innovative funding solutions that promote RES.

The paradox is the fact that by maturing, renewable energy must gradually become part of the market, thus potentially increasing the risks taken by investors. The current regulatory developments therefore appear to be changing the field for energy transitions and giving rise to innovative financing solutions that are to be encouraged to eventually achieve the ambitious objectives needed. 


\section{References}

[1] Yonghong Kuang, Yongjun Zhang, Bin Zhou, Canbing Li, Yijia Cao, Lijuan Li, and Long Zeng. A review of renewable energy utilization in islands. Renewable and Sustainable Energy Reviews, 59:504-513, jun 2016.

[2] G. Baldacchino. A World of Islands: An Island Studies Reader. Agenda Publishers, 2007.

[3] M Pelling and J Uitto. Small island developing states: natural disaster vulnerability and global change. Global Environmental Change Part B: Environmental Hazards, 3(2):49-62, June 2001.

[4] Lino Briguglio. Small island developing states and their economic vulnerabilities. World Development, 23(9):1615-1632, September 1995.

[5] Prakash N K Deenapanray and Andrea M Bassi. The experience of ISLANDS in deploying system dynamics modeling as an integrated policy tool. Natural Resources Forum, 38(1):67-81, February 2014.

[6] L A Nurse, R F McLean, J Agard, L P Briguglio, V Duvat-Magnan, N Pelesikoti, E Tompkins, and A Webb. Small islands. In V R Barros, C B Field, D J Dokken, M D Mastrandrea, K J Mach, T E Bilir, M Chatterjee, K L Ebi, Y O Estrada, R C Genova, B Girma, E S Kissel, A N Levy, S MacCracken, P R Mastrandrea, and L L White, editors, Climate Change 2014: Impacts, Adaptation, and Vulnerability. Part B: Regional Aspects. Contribution of Working Group II to the Fifth Assessment Report of the Intergovernmental Panel of Climate Change, pages 1613-1654. Cambridge University Press, Cambridge, United Kingdom and New York, NY, USA, 2015.

[7] Mehmet Balcilar, Ali M. Kutan, and Mehmet E. Yaya. Testing the dependency theory on small island economies: The case of cyprus. Economic Modelling, 61:1-11, feb 2017.

[8] Luis Chen, Fengzhen and Duic, Neven and Manuel Alves and Maria da Graça Carvalho. Renewislands-Renewable energy solutions for islands. Renewable and Sustainable Energy Reviews, 11(8):1888-1902, October 2007.

[9] Mohammad Khalil Elahee. Sustainable energy policy for small-island developing state: Mauritius. Utilities Policy, 19(2):7179, June 2011.

[10] Theocharis Tsoutsos, Maria Drandaki, Niki Frantzeskaki, Eleftherios Iosifidis, and Ioannis Kiosses. Sustainable energy planning by using multi-criteria analysis application in the island of Crete. Energy Policy, 37(5):1587-1600, 2009.

[11] S.K. Singal and R.P. Singh. Rural electrification of a remote island by renewable energy sources. Renewable Energy, 32(15):2491-2501, December 2007.

[12] Emmanouil K. Oikonomou, Vassilios Kilias, Aggelos Goumas, Alexandrous Rigopoulos, Eirini Karakatsani, Markos Damasiotis, Dimitrios Papastefanakis, and Natassa Marini. Renewable energy sources (RES) projects and their barriers on a regional scale: The case study of wind parks in the Dodecanese islands, Greece. Energy Policy, 37(11):4874-4883, November 2009.

[13] Neven Duić and Maria da Graça Carvalho. Increasing renewable energy sources in island energy supply: case study Porto Santo. Renewable and Sustainable Energy Reviews, 8(4):383-399, August 2004.

[14] Matthew Dornan and Kalim U. Shah. Energy policy, aid, and the development of renewable energy resources in small island developing states. Energy Policy, 98:759-767, nov 2016.

[15] Ravita D. Prasad, R.C. Bansal, and Atul Raturi. A review of fiji's energy situation: Challenges and strategies as a small island developing state. Renewable and Sustainable Energy Reviews, nov 2016.

[16] Kalim U. Shah and Keron Niles. Energy policy in the caribbean green economy context and the institutional analysis and 
design (IAD) framework as a proposed tool for its development. Energy Policy, 98:768-777, nov 2016.

[17] Henning Meschede, Michael Child, and Christian Breyer. Assessment of sustainable energy system configuration for a small canary island in 2030. Energy Conversion and Management, 165:363 - 372, 2018.

[18] Diana Neves, Carlos A. Silva, and Stephen Connors. Design and implementation of hybrid renewable energy systems on micro-communities: A review on case studies. Renewable and Sustainable Energy Reviews, 31:935 - 946, 2014.

[19] Henning Meschede, Peter Holzapfel, Florian Kadelbach, and Jens Hesselbach. Classification of global island regarding the opportunity of using res. Applied Energy, 175:251 - 258, 2016.

[20] Leila Marchand. « l'île de tesla ", entièrement alimentée aux panneaux solaires.

https://www.lesechos.fr/26/11/2016/1esechos.fr/0211523874648_ --1-ile-de-tesla----entierement-alimentee-aux-panneaux-solaires.htm November 2016.

[21] J.P Painuly. Barriers to renewable energy penetration; a framework for analysis. Renewable Energy, 24(1):73 - 89, 2001.

[22] Valérie Angeon and Jean-François Hoarau. Les petites économies insulaires : un monde à part entière? Nouveaux regards conceptuels et méthodologiques. Région et Développement, 42:5-13, 2015.

[23] INSEE. Tableau Economique de la Réunion. Technical report, 2014.

[24] Souvik Sen and Sourav Gangulyb. Opportunities, barriers and issues with renewable energy development - A discussions. Renewable and Sustainable Energy Reviews, Article in press, 2016.

[25] SPL Energies Réunion. Bilan énergétique. Technical report, 2015.

[26] Mashael Yazdanie, Martin Densing, and Alexander Wokaun. The role of decentralized generation and storage technologies in future energy systems planning for a rural agglomeration in switzerland. Energy Policy, 96:432 - 445, 2016.

[27] R. C. Dugan, T. E. McDermott, and G. J. Ball. Planning for distributed generation. IEEE Industry Applications Magazine, 7(2):80-88, Mar 2001.

[28] H. A. Gil and G. Joos. Models for quantifying the economic benefits of distributed generation. IEEE Transactions on Power Systems, 23(2):327-335, May 2008.

[29] V.H. Méndez, J. Rivier, J.I. de la Fuente, T. Gómez, J. Arceluz, J. Marín, and A. Madurga. Impact of distributed generation on distribution investment deferral. International Journal of Electrical Power Energy Systems, 28(4):244 - 252, 2006.

[30] Rahmatallah Poudineh and Tooraj Jamasb. Distributed generation, storage, demand response and energy efficiency as alternatives to grid capacity enhancement. Energy Policy, 67:222 - 231, 2014.

[31] Mudathir Funsho Akorede, Hashim Hizam, and Edris Pouresmaeil. Distributed energy resources and benefits to the environment. Renewable and Sustainable Energy Reviews, 14(2):724 - 734, 2010.

[32] P. Chiradeja and R. Ramakumar. An approach to quantify the technical benefits of distributed generation. IEEE Transactions on Energy Conversion, 19(4):764-773, Dec 2004.

[33] A.G. Tsikalakis and N.D. Hatziargyriou. Environmental benefits of distributed generation with and without emissions trading. Energy Policy, 35(6):3395 - 3409, 2007.

[34] Laure Dobigny. L'autonomie énergétique : acteurs, processus et usages. de l'individuel au local en allemagne, autriche, france. In Consommer autrement. La réforme écologique des modes de vie. Paris, L'Harmattan, 2009.

[35] S. Ould Amrouche, D. Rekioua, T. Rekioua, and S. Bacha. Overview of energy storage in renewable energy systems. International fournal of Hydrogen Energy, 41(45):20914-20927, dec 2016. 
[36] Fiona Bénard-Sora and Jean Philippe Praene. Territorial analysis of energy consumption of a small remote island: Proposal for classification and highlighting consumption profiles. Renewable and Sustainable Energy Reviews, 59:636-648, jun 2016.

[37] JORF. Loi n2015-992 du 17 août 2015 relative á la transition énergétique pour la croissance verte.

[38] Valentin Bertsch, Margeret Hall, Christof Weinhardt, and Wolf Fichtner. Public acceptance and preferences related to renewable energy and grid expansion policy: Empirical insights for germany. Energy, 114:465-477, nov 2016.

[39] Bernadette Sütterlin and Michael Siegrist. Public acceptance of renewable energy technologies from an abstract versus concrete perspective and the positive imagery of solar power. Energy Policy, 106:356-366, jul 2017.

[40] EDF. Systemes energetiques insulaires la reunion. Technical report, EDF, 2017.

[41] Jean Philippe Praene, Mathieu David, Frantz Sinama, Dominique Morau, and Olivier Marc. Renewable energy: Progressing towards a net zero energy island, the case of reunion island. Renewable and Sustainable Energy Reviews, 16(1):426-442, jan 2012.

[42] INSEE Réunion. INSEE Flash n10: Comptes économiques définitifs de la Réunion. Technical report, November 2014.

[43] INSEE Réunion. INSEE Conjoncture n3: Bilan économique 2016, la croissance s’installe. Technical report, 2017.

[44] Vanessa Rakotoson, Laetitia Adélard, and Jean Philippe Praene. Évaluation des émissions de gaz à effet de serre du mix électrique de territoires insulaires. In Conférence IBPSA France - Marne-la-Vallée - 2016, 2016.

[45] Jean Philippe Praene, Mathieu David, Frantz Sinama, Dominique Morau, and Olivier Marc. Renewable energy: Progressing towards a net zero energy island, the case of reunion island. Renewable and Sustainable Energy Reviews, 16(1):426 - 442, 2012.

[46] Ministère de l'Ecologie et de l'Energie. Arrêté du 23 avril 2008, April 2008. NOR: DEVE0808815A, Available at: https://www.legifrance.gouv.fr/affichTexte.do?cidTexte=JORFTEXT000018698004 [accessed 1 November February 2016].

[47] Mathilde Drouineau, Edi Assoumou, Vincent Mazauric, and Nadia Maïzi. Increasing shares of intermittent sources in Reunion Island: Impacts on the future reliability of power supply. Renewable and Sustainable Energy Reviews, 46:120-128, June 2015.

[48] Ministère de l'Egalité des territoires et du logement Ministère de l'Ecologie, du développement durable et de l'Energie. Décret nº 2009-424, 2009. ère de l'Egalité des territoires et du logementurlhttps://www.legifrance.gouv.fr/eli/decret/2009/4/17/DEVU0811478D/jo/texte

[49] IEA. World Energy Statistics 2016. Organization for Economic Co-operation and Development (OECD), 2016.

[50] Jean-Marie Chevalier. Les nouveaux défis de l'énergie. Climat - Economie - Géopolitique. Economica, Paris, 2009.

[51] JORF. Loi n2005-781 du 13 juillet 2005 de programme fixant les orientations de la politique énergétique, 2005.

[52] JORF. Loi n2010-788 du 12 juillet 2010 portant engagement national pour l'environnement, 2010.

[53] JORF. Loi n2009-967 du 3 août 2009 de programmation relative à la mise en œuvre du Grenelle de l'environnement (1), 2009.

[54] Ministère de l'environnement de l'énergie et de la mer. La transition energetique en marche: 212 territoires à énergie positive, 2015.

[55] France. Code de l'urbanisme, version consolidée au 22 mars 2015, 2015.

[56] Mairie de Saint-Leu; Duteilh-Perrau Urbanisme. Elaboration du Plan Local d’Urbanisme, Réglement Ecrit, 2007. 